\title{
Immunohistochemical Study of Acute Effects of Ethanol on Midbrain of Wistar Rats Associated with the Date of Birth of Neurons in Encephalon
}

\author{
Estudio Inmunohistoquímico de los Efectos Agudos del Etanol sobre el Mesencéfalo de Ratas \\ Wistar Asociado con la Fecha de Formación de Neuronas en el Cerebro
}

Danielly Bandeira Lopes; Guilherme Nobre Lima do Nascimento; Adryano Augustto Valladão de Carvalho; Advaldo Carlos de Souza Neto; Natácia Evangelista de Lima \& Tales Alexandre Aversi-Ferreira

LOPES, D. B.; NASCIMENTO, G. N. L.; CARVALHO, A. A. V.; NETO, A. C. S.; LIMA, N. E. \& AVERSI-FERREIRA, T. A. Immunohistochemical study of acute effects of ethanol on midbrain of Wistar rats associated with the date of birth of neurons in encephalon. Int. J. Morphol., 27(3):677-682, 2009.

SUMMARY: The verification of the acute effects of ethanol on the midbrain, which neurons are mainly formed in E14, will ratify if the acute effects of ethanol are associated, in terms of prevalence, to the date of birth of neurons in certain regions of the brain. The aim of this study was to determine the effects of acute exposure to ethanol on the neuronal density of the midbrain and to associate these results with acute effects of ethanol in other regions of the brain under the same conditions. The rats were treated with intraperitoneal ethanol during one day (E12) and $1 \mathrm{~h}$ after the last ethanol injection was applied to BrdU. The animals were sacrificed; the brains were removed and sectioned. The sections were treated with DAB for the BrdU revelation, the slides were stained with safranin for one group and another group was stained with $\mathrm{H} \& \mathrm{E}$. The effects of acute injection of ethanol in E12 on the midbrain were not detected in this study. Data from literature suggest that the deleterious action of acute ethanol consumption only occur if the drug is injected at times near the beginning of the migration of neurons in that particular region of the brain.

KEY WORDS: Ethanol; Brain; Midbrain; Neuronal migration; Fetal Alcohol Syndrome.

\section{INTRODUCTION}

The development of the neural system involves a series of time and space dependent events, being related to the date of birth of the neurons and their interaction with the radial glia (Wilsnack et al., 1984; Chevassus-Au-Louis et al., 1998; Luhmann et al., 1998; Redecker et al., 1998; VelezDomingues, 1998; Aversi-Ferreira et al., 2004; AversiFerreira et al., 2005; Aversi-Ferreira et al., 2006, AversiFerreira \& Nascimento, 2008).

The pre-natal exposure to ethanol is responsible for a series of fetal disturbances and malformations, which could result in severe anatomy-physiological effects in the newborn characterizing a disease known as Fetal Alcohol Syndrome (Shetty et al., 1992; Miller, 1993; Valles et al., 1996; VelezDomingues; Aversi-Ferreira et al., 2004; Aversi-Ferreira \& Penha-Silva, 2005; Aversi-Ferreira \& Nascimento). This syndrome is characterized by microencephaly, loss of selectivity of neuronal cells, decrease on the density of projections, cell death, aberrations in migration, among others (Miller; Valles et al.; Liesi, 1997).

The deleterious effects of fetal alcohol syndrome refers to the chronic exposure to ethanol, already fairly well known (Aversi-Ferreira \& Penha-Silva), but recent studies have shown that even the acute exposure in E12 (twelfth day of the intrauterine life development), which corresponds to the date of birth of neurons in the neocortex of rats and, putatively, the thirtieth day in humans female, generates damage similar to the chronic effects on the prefrontal cortex, on the neocortex in general and on the olfactory bulb (AversiFerreira et al., 2004; Aversi-Ferreira \& Penha-Silva; AversiFerreira et al., 2005; Aversi-Ferreira et al., 2006; Aversi-

Department of Morphology - Institute of Biological Sciences Federal University of Goiás, Goiânia-GO, Brazil. 
Ferreira \& Nascimento). However, these effects were not observed on the cerebellum, since the neurons in this region have their date of birth in E10 (Souza et al., 2006); therefore, the doses of ethanol did not affect the formation of the cerebellum neuroblasts.

The verification of the acute effects of ethanol on the midbrain, which neurons are formed between E12 and E15 with most starting the migration in E14 (Pardo et al., 1997), can help to ratify the hypothesis if the acute effects of ethanol are associated, in terms of prevalence, to the date of birth of neurons in certain regions of the brain.

The midbrain is a little and thin segment in brain trunk between the above of the pons and cerebellum, and unite both to prosencephalum (Gray, 1988) and it is the relay station of pyramidal neurons originated in the premotor cortex. The dopaminergics neurons of the midbrain are important to voluntary movement, working memory and recompense system. Problems in its structure may cause motor disorders associated with Parkinsonism, also esquizophreny and attention deficit that can be caused by drugs abuse, including alcohol (Goldman-Rakic, 1999; Kitai et al., 1999; Spanagel \& Weiss, 1999; Dunnet \& Bjorklund, 1999; Verhoeff, 1999; Berke \& Hyman, 2000; Grace, 2000; Svensson, 2000; Tzschentke, 2001; Korotkova et al., 2004).

The main of this study was verify the citoarchitecture of midbrain under ethanol acute action and associate the results with the observed in other regions of the brain under the same conditions, that is ethanol injection in 12th intraembrionary day of gestation in Wistar rats.

\section{MATERIAL AND METHOD}

Female Wistar rats $(180-230 \mathrm{~g} \pm 15 \mathrm{~g})$ were housed overnight with male rats. The presence of a vaginal plug and sperm in the vagina confirmed successful mating and indicated the first day of gestation (E0). Eighteen-day pregnant female rats were housed in cages at $22 \pm 0.4^{\circ} \mathrm{C}$, on a $12 \mathrm{~h}$ light/dark cycle, with free access to food and water.

On the $12^{\text {th }}$ day of pregnancy (E12), 12 rats received three intraperitoneal injections of a $20 \%$ ethanol solution ( $3 \mathrm{~g}$ of ethanol $/ \mathrm{kg}$ of body weight) at $8 \mathrm{~h}$ intervals (AversiFerreira et al., 2004). Ethanol was administered intraperitoneally because this route ensured that all rats received an equal volume and amount of drug and absorption of almost $99.99 \%$. Also, at E12, six control pregnant rats received saline injections of $0.9 \%$ at the same intervals as the ethanol-treated rats. Proliferating cells were labeled as described elsewhere. All rats received a single intraperitoneal injection of $\mathrm{BrdU}(5 \mathrm{mg} / \mathrm{mL}$ in $0.9 \% \mathrm{NaCl}$, containing $70 \mathrm{mM} \mathrm{NaOH}$ ) at a dose of $60 \mathrm{mg} / \mathrm{kg} 2 \mathrm{~h}$ after the last injection of ethanol or saline solution. At the $8^{\text {th }}$ day of postnatal life (P8), all 18 litters were anesthetized with sodium pentobarbital (50 mg/kg, i.p.), and perfused with saline followed by $70 \%$ ethanol.

The brains were removed and processed as described elsewhere. Briefly, the brains were embedded in paraffin, sectioned seriate saggitally ( $7 \mu \mathrm{m}$ thick sections), and mounted on gelatin-coated slides. The sections were deparaffinized, hydrated in a graded ethanol series and treated with $1 \mathrm{M} \mathrm{NaOH}$ followed by $1 \mathrm{M}$ sodium borate buffer (20 min each), prior to washing with phosphate buffer. After blocking non-specific sites with serum, the sections were incubated for $2 \mathrm{~h}$ with a monoclonal anti-BrdU antibody (diluted 1:500; Sigma, St. Louis, MO, USA) followed by incubation for $1 \mathrm{~h}$ with a goat anti-rat secondary antibody (diluted 1:200; Vector, Burlingame, CA, USA) and then treated with an avidin-biotin complex (Vector) and incubated with 3,3'-diaminobenzidine (Sigma). The slices were stained by safranine and hematoxylin and eosin.

Sections were cover slipped with entellan. The cells were counting by microscopic area (Olympus CX41) to objective of 40X $\left(610200 \mu \mathrm{m}^{2}\right)$ and analyzed by Image $\mathrm{J}$ program $1.38 \mathrm{X}$ version. Slices stained with safranine (80 images) were counted in separated in relation to those stained by hematoxylin and eosin (80 images). Data were analyzed statistically using ANOVA and Student's t-test, with a significance of $\mathrm{p}<0.05$. All statistical analyses were conducted using the Origin 6.0 software (Microcal Software Inc.). The experimental protocols described here were approved by the institutional ethics research committee of the Goiás Federal University.

\section{RESULTS}

The counting of cells (Fig. 1) by field in the midbrain (Fig. 2) demonstrated no significant difference between samples for $\mathrm{p}<0.05$ through the t-test for the Analysis of Variance (ANOVA).

The slides stained with safranin (Fig. 2) show only the nuclei of cells that started the migration around E12, since they do not mark the other cells in the field, which do not present the revelation of BrdU with DAB. The slides stained with hematoxylin and eosin (Fig. 3) show all cells of the field. 


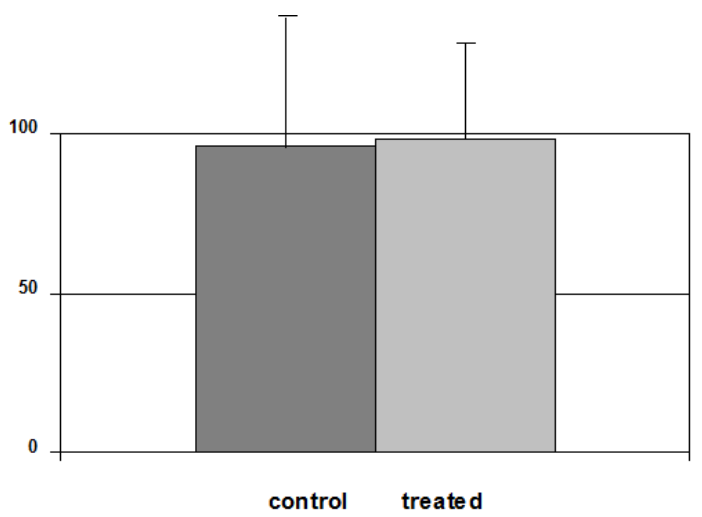

Fig. 1. Count of cells of the midbrain by area of $610200 \mu \mathrm{m}^{2}$ in " $y$ " axis to control (dark) and treated (ashen) animals. No significant difference between samples was observed in the " $\mathrm{t}$ " test at $\mathrm{p}<0.05$.

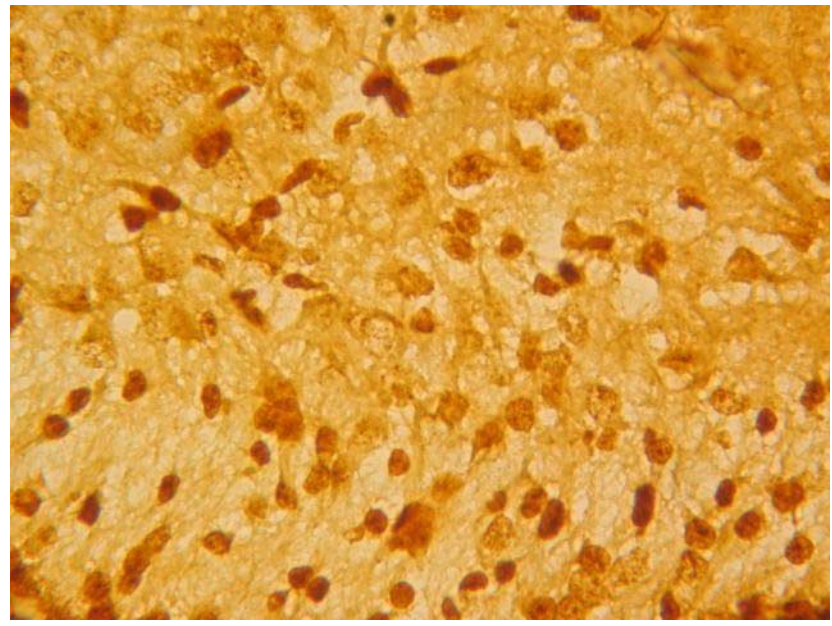

Fig. 2. Photomicrography of the midbrain of Wistar rat contrasted with safranin, whose mother was treated with ethanol, born in P8. Cells with dark nuclei in the photomicrography were marked with BrdU in E12 (400X).

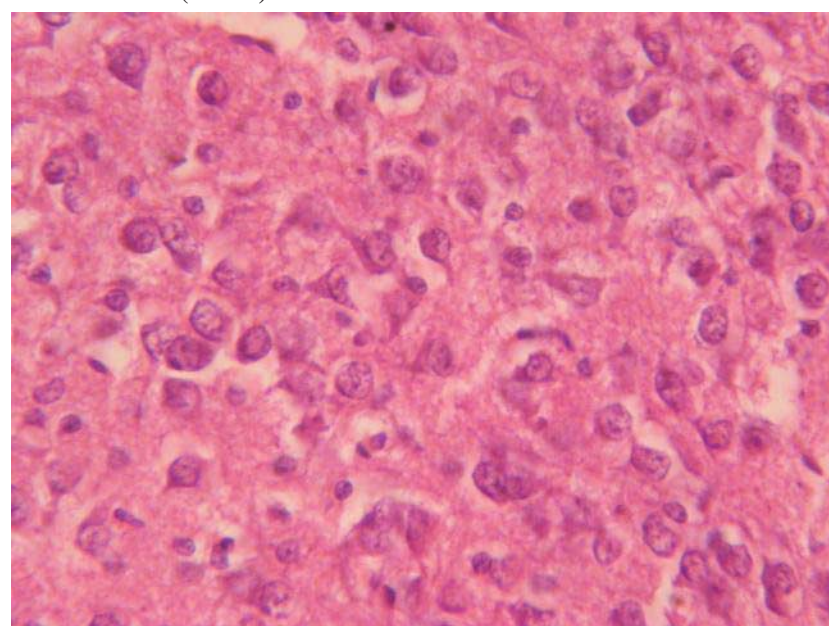

Fig. 3. Photomicrography of midbrain contrasted with hematoxilin and eosin. In this image there are more cells by area in relationship Figure 2, because the H\&E evidence the total cells in field, not only the cells that were impregnated by BrdU in E12 (400x).

\section{DISCUSSION}

The acute effects of ethanol on the migration of cells in the brain were very serious (Aversi-Ferreira et al., 2004; Aversi-Ferreira \& Penha-Silva; Aversi-Ferreira et al., 2005; Aversi-Ferreira et al., 2006; Aversi-Ferreira \& Nascimento), but only for acute applications of ethanol on the date of birth of neurons of these areas (Fig. 4), since in the cerebellum which date of birth of neurons occurs around E10 and E12, 5 (Souza et al.), which means that the cells had migrated at the time of the acute injection of ethanol, and no difference between the treated and control groups was observed (Fig. 5).

Other encephalic areas, how olfactory bulb, that the neuron formation begin in previous period to E12, the acute ethanol exposition doesn't cause evident heterotopy and ectopy, but it causes diminution of cells (Fig. 4A) (AversiFerreira et al., 2006).

The migration of neuronal cells at the neocortex begins around E12. The effects in this pre-frontal cortex submitted at the same conditions described in our study caused a decreased of neuronal density, mainly at the layers II e VI of the cortex (Fig. 4B) (Aversi-Ferreira et al., 2004). Other cerebral regions were affected by this kind of exposition. Heterotopia had been observed in all cerebral lobes of the animals treated with ethanol and, also had detected loss of neuronal density in the parietal, occipital and temporal lobes. (Aversi-Ferreira et al., 2004; AversiFerreira \& Penha-Silva; Aversi-Ferreira et al., 2005). Based in these considerations, we could suppose that the deleterious effects of ethanol at the neocortex are proximately at the date of neuronal born.

Despite the deleterious and important acute effects of ethanol on the neocortex disorganization, the cell counting data, associated with the cerebellum (Fig. 5) and to the midbrain, which migration starts, especially after E12, indicate that the prevalence of lesions occur in specific days, which are the days that the migration of neurons to each region begins. Our data show that there are $32 \%$ more cells in the area evidenced through slides stained with hematoxylin and eosin in relation to those stained with safranin (Figs. 2 and 3). This shows that there was a large contingent of migration of cells to the midbrain after E12, day that BrdU was injected, and that only a small contingent of these cells was affected by the acute injection of ethanol in E12, since the majority of neurons in the midbrain initiate their migration in E14 (Pardo et al.).

The acute use of ethanol during pregnancy can cause serious problems on the brain. Indeed, studies on the effect 


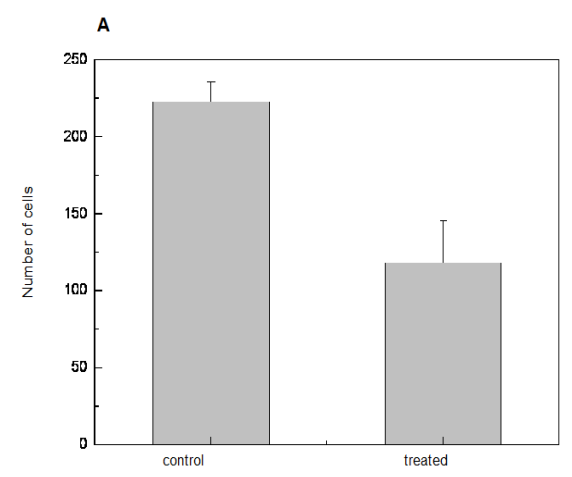

Fig. 4. Count of cells by area of $15.000 \mu \mathrm{m}^{2}$ in "y" axis in encephalon regions where the birthday of neurons occurs in E12, which (A) represent the count to olfactory bulb and (B) count to lobes of the cortex.

B

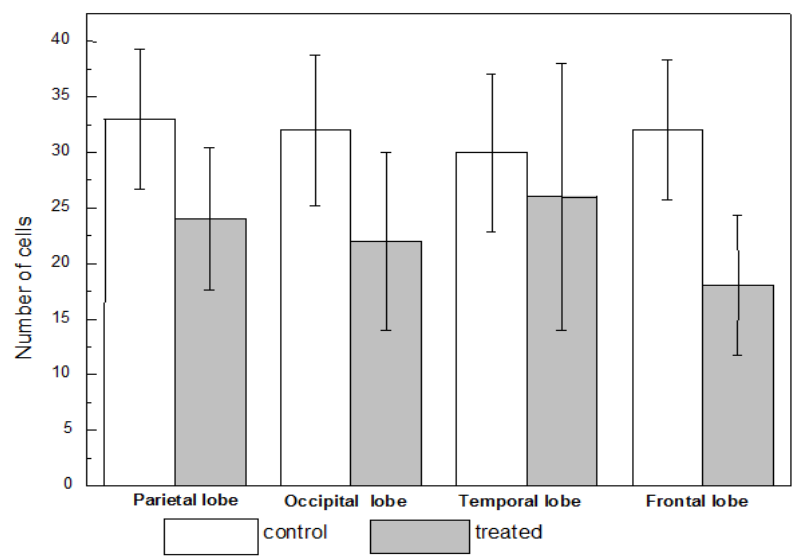

of ethanol on the nervous system have demonstrated high severity level of this drug on the nervous system in chronic (Shetty et al.; Miller; Valles et al.; Liesi; VelezDomingues) and acute consumption (Aversi-Ferreira $e t$ al., 2004; Aversi-Ferreira \& Penha-Silva; Aversi-Ferreira et al., 2005). In this way, others studies may be made to verify possible behavioral deviation of offspring after ethanol injection on your mothers.

Aversi-Ferreira \& Nascimento, in a recent literature reviewed, reported that studies on the acute effect of ethanol on the nervous system are scarce, mainly on specific days of the brain development and, the studies about chronic effects of ethanol on the nervous system don't explain how is the ethanol act on the neuron or cells structure. Ikonomidou et al. (2000) also consider that the deleterious effects of ethanol on developing human encephalon are poorly understood, and more studies are necessary to understand the ethanol's action on the nervous system.

Penha-Silva et al. (2008) had verified the deleterious effects of ethanol on membrane stability, indicating a general effects of the ethanol on cellular structure.
Some points can be considered to alert the society on the ethanol consumption, mainly females with pregnancy suspect, because the acute consumption of ethanol generates important disturbances to the offspring in rats, considering what Caviness Jr. (1975) cites, that humans and rats have the same neural substrate and the neural structure and the connections are identical to all mammalians species.

These aspects are very important to stimulate more studies on ethanol and its action on tissues and, cellular and molecular structures involved in the cellular migration process in the nervous system. Other days of gestation else than E12 should be studied, because only a few references (Aversi-Ferreira et al., 2004; AversiFerreira \& Penha-Silva; Aversi-Ferreira et al., 2005; Souza et al.; Aversi-Ferreira \& Nascimento) on this topic were currently found in literature.

Our data suggest that the neural system under development is more susceptible to the effects of ethanol during migration, and that after the establishment of the neurons destination, a morphophysiological and perhaps biochemical maturity can occurs for effectuate the detoxification.
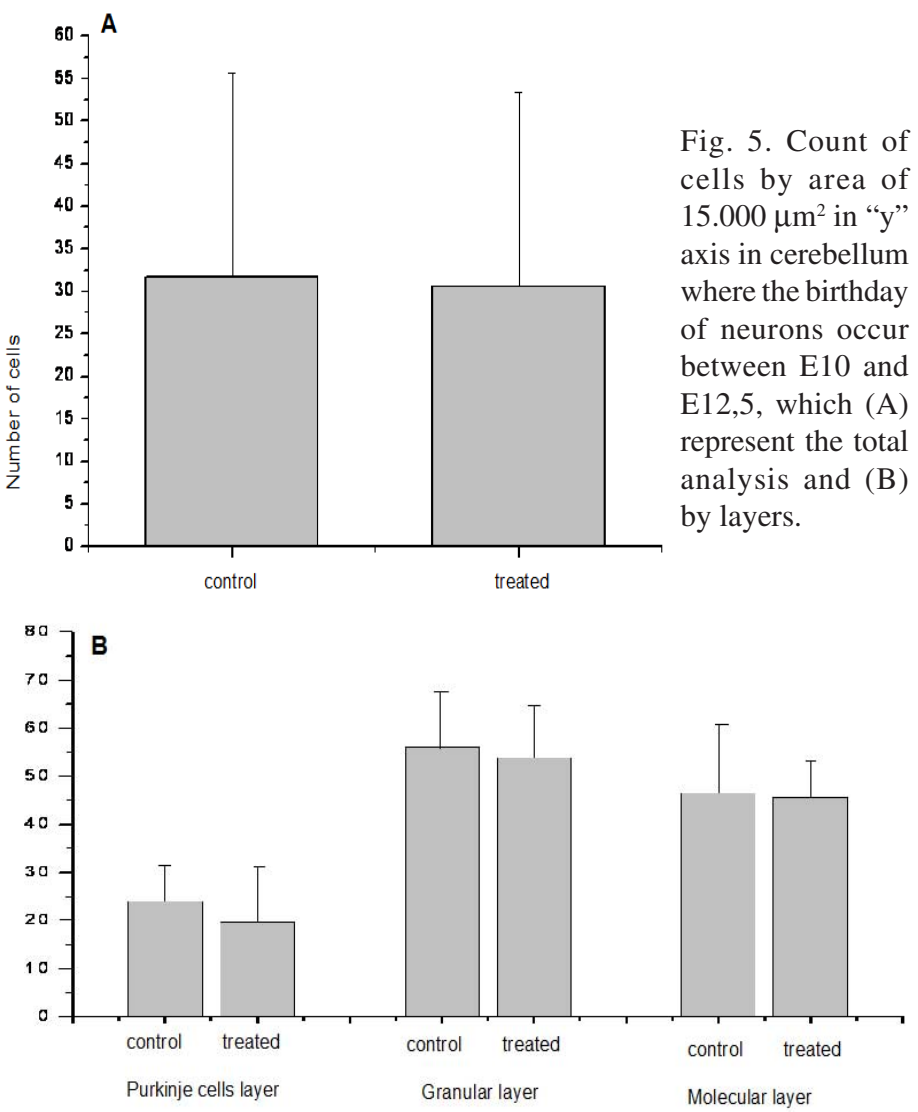
LOPES, D. B.; NASCIMENTO, G. N. L.; CARVALHO, A. A. V.; NETO, A. C. S.; LIMA, N. E. \& AVERSI-FERREIRA, T. A. Immunohistochemical study of acute effects of ethanol on midbrain of Wistar rats associated with the date of birth of neurons in encephalon. Int. J. Morphol., 27(3):677-682, 2009.

LOPES, D. B.; NASCIMENTO, G. N. L.; CARVALHO, A. A. V.; NETO, A. C. S.; LIMA, N. E. \& AVERSI-FERREIRA, T. A. Estudio inmunohistoquímico de los efectos agudos del etanol sobre el mesencéfalo de ratas Wistar asociado con la fecha de nacimiento de neuronas en el cerebro.Int. J. Morphol., 27(3):677-682, 2009.

RESUMEN: La verificación de los efectos agudos del etanol sobre el mesencéfalo, cuyas neuronas se forman principalmente en la E14, puede ratificar si los efectos agudos del etanol están asociados, en términos de prevalencia, a la fecha de nacimiento de neuronas en ciertas regiones del cerebro. El objetivo de este estudio fue determinar los efectos de la exposición aguda al etanol sobre la densidad neuronal del mesencéfalo y asociar estos resultados con los efectos agudos de etanol en otras regiones del cerebro bajo las mismas condiciones. Las ratas fueron tratadas con etanol intraperitoneal durante un día (E12) y 1h después de la última inyección de etanol fue aplicado BrdU. Los animales fueron sacrificados, los cerebros fueron removidos y seccionados. Las secciones fueron tratados con DAB para la revelación de $\mathrm{BrdU}$, las secciones fueron teñidas con safranina para un grupo y otro grupo se tiñeron con H\&E. Los efectos agudos de la inyección de etanol en E12 sobre el mesencéfalo no fueron detectados en este estudio. Los datos de la literatura sugieren que los efectos deletéreos del consumo agudo de etanol sólo se producen si la droga se inyecta en etapas cercanas al comienzo de la migración de las neuronas en esa región particular del cerebro.

PALABRAS CLAVE: Etanol; Cerebro; Mesencéfalo; Migración neuronal; Síndrome de Alcoholismo Fetal.

\section{REFERENCES}

Aversi-Ferreira, T. A. \& Nascimento, G. N. L. The effect of acute and chronic exposure to ethanol on the developing encephalon: a review. Rev. Bras. Saude Mater. Infant., $8(3): 241-9,2008$.

Aversi-Ferreira, T. A. \& Penha-Silva, N. Effects of ethanol on the neuronal migration in the brain neocortex formation. Biosci. J., 21(1):151-7, 2005

Aversi-Ferreira, T. A.; Correa, N. C. R.; Morais, J. O. R. \& Penha-Silva, N. Posnatal effects of ethanol on neocortical neurogenesis in Wistar rats. Neurociências, 2(6):304-10, 2005.

Aversi-Ferreira, T. A.; Ferreira, N. R.; Morais, J. O. R. \& Penha-Silva, N. Effects of acute prenatal exposure to ethanol on the postnatal morphology of the prefrontal córtex in Wistar rats. Braz. J. Morphol. Sci., 21(2):97$101,2004$.

Aversi-Ferreira, T. A.; Rodrigues, H. G.; Neres, A. C.; Fonseca, L. C. \& Penha-Silva, N. Estudo imunohistoquímico do bulbo olfatório de ratos Wistar submetidos à exposição pré-natal aguda com etanol. Biosci. J., 22(1):99-105, 2006.

Berke, J. D. \& Hyman, S. E. Addiction, dopamine, the molecular mechanisms of memory. Neuron, 25:515-32, 2000.

Caviness Jr. V. S. Architetonic map of neocortex of the normal mouse. J. Comp. Neurol.,164:247-63, 1975.

Chevassus-Au-Louis, N.; Congar, P.; Represa, A.; Ben-Ari,
Y. \& Gaiarsa, J. L. Neuronal migration disorders: heterotopic neocortical neurons in CA1 provide a bridge between the hippocampus and the neocortex. Proc. Natl. Aca. Sci. USA, 95(17):10263-8, 1998.

Dunnet, S. B. \& Bjorklund, A. Prospects for new restorative and neuroprotective treatments in Parkinson's disease. Nature, 399:A32-9, 1999.

Goldman-Rakic, P. S. The physiological approach: functional architecture of working memory and disordered cognition in schizophrenia. Biol. Psychiatry, 46:650-61, 1999.

Grace, A. A. The tonic/phasic model of dopamine system regulation and its implications for understanding alcohol and psychostimulant craving. Addiction, 95(2):S119$28,2000$.

Gray, H. O Sistema Nervoso Central. In: Anatomia, 29ª Ed. Rio de Janeiro, Guanabara Koogan, 1988. pp.636-740.

Ikonomidou, C.; Bittigau, P.; Ishimaru, M. J.; Wozniak, D. F.; Koch, C.; Genz, K.; Price, M. T.; Stefovska, V.; Horster, F.; Tenkova, T.; Dikranian, K. \& Olney, J. W. Ethanol-induced apoptotic neurodegeneration and fetal alcohol syndrome. Science, 287:1056-60, 2000.

Kitai, S. T.; Shepard, P. D.; Callaway, J. C. \& Scroggs, R. Afferent modulation of dopamine neuron firing patterns. Curr. Opin. Neurobiol., 9:690-7, 1999.

Korotkova, T. M.; Ponomarenko, A. A.; Brown, R. E. \& Haas, H. L. Functional diversity of ventral midbrain dopamine and GABAergic neurons. Mol. Neurobiol., 29:243-59, 2004. 
LOPES, D. B.; NASCIMENTO, G. N. L.; CARVALHO, A. A. V.; NETO, A. C. S.; LIMA, N. E. \& AVERSI-FERREIRA, T. A. Immunohistochemical study of acute effects of ethanol on midbrain of Wistar rats associated with the date of birth of neurons in encephalon. Int. J. Morphol., 27(3):677-682, 2009.

Liesi, P. Ethanol-exposed central neurons fail to migrate and undergo apoptosis. J. Neurosci. Res., 48(5):439-48, 1997.

Luhmann, H. J.; Karpuk, N.; Qu, M. \& Zilles, K. Characterization of neuronal migration disorders in neocortical structures. II. Intracellular in vitro recordings. J. Neurophysiol., 80(1):92-102, 1998.

Miller, M. W. Migration of cortical neurons is altered by gestational exposure to ethanol. Alcoholism. Clin. Exp. Res., 17(2):304-14, 1993.

Pardo, B.; Paino, C. L.; Casarejos, M. J. \& Mena, M. A. Neuronal-enriched cultures from embryonic rat ventral mesencephalon for pharmacological studies of dopamine neurons. Brain Res. Brain Res. Protoc., 1(2):127-32, 1997.

Penha-Silva, N.; Arvelos, L. R.; Cunha, C. C.; AversiFerreira, T. A.; Gouvêa-e-Silva, L. F.; Garrote-Filho, M. S.; Finotti, C. J.; Bernardino-Neto, M. \& De Freitas Reis, F. G. Effects of glycerol and sorbitol on the thermal dependence of the lysis of human erythrocytes by ethanol. Bioeletrochemistry, 73(1):23-9, 2008.

Redecker, C.; Hagemann, G.; Witte, O. W.; Marret, S.; Evrard, P. \& Gressens, P. Long term evolution of excitotoxic cortical dysgenesis induced in the developing rat brain. Brain Res. Dev., 109(1):109-13, 1998.

Shetty, A. K.; Burrows, R. C. \& Phillips, D. E. Alterations in neural development in the substantia nigra pars compacta following in utero ethanol exposure: immunohistochemical and golgi studies. Neuroscience, 52(2):311-22, 1993.

Souza, A. G.; Rodrigues, H. G.; Serpa-Vieira, C. M.; Mateus, M. V. \& Aversi-Ferreira, T. A. Estudo imunohistoquímico do cerebelo de ratos Wistar submetidos à exposição aguda ao etanol no $12^{\circ}$ dia de vida intrauterina. Revista Eletrônica de Farmácia, 3(2):6-14, 2006.

Spanagel, R. \& Weiss, F. The dopamine hypothesis of reward: past and current status. Trends Neurosci., 22:521-7, 1999.

Svensson, T. H. Dysfunctional brain dopamine systems induced by psychotomimetic NMDA-receptor antagonists and the effects of antipsychotic drugs. Brain Res. Rev., 31:320-9, 2000.

Tzschentke, T. M. Pharmacology and behavioral pharmacology of the mesocortical dopamine system. Prog. Neurobiol., 63:241-320, 2001.
Valles, S.; Sancho-Tello, M.; Minãna, R.; Climent, E., RenauPiquerasm, J. \& Guerri, C. Glial fibrillary acidic protein expression in rat brain and in radial glia culture is delayed by prenatal ethanol exposure. J. Neurochem., 67(6):242533, 1996.

Velez-Dominguez, L. C. Transtornos de migration neuronal. Gac. Med. Mex., 134(2):207-15, 1998.

Verhoeff, N. P. Radiotracer imaging of dopaminergic transmission in neuropsychiatric disorders. Psychopharmacology, 147:217-49, 1999.

Wilsnack, S. C.; Klassen, A. D. \& Wilsnack, R. W. Drinking and reproductive dysfunction among women in a 1981 national surgery. Alcohol Clin. Exp. Res., 8(5):451-8, 1984.

Correspondence to:

Dr. Tales Alexandre Aversi-Ferreira

Federal University of Goiás - UFG

BRAZIL

Email: aversiferreira@hotmail.com.br

Received: 22-02-2009

Accepted: 27-07-2009 